\title{
Catch composition of set net (fixed stake trap) fisheries in the coastal waters of Saros Bay, North Aegean Sea
}

\section{Saros Körfezi'nin (Kuzey Ege Denizi) kıyısal sularında ağ dalyan balıkçılığının av kompozisyonu}

\author{
Serhat Çolakoğlu1* • Adnan Tokaç² • Ali İşmen ${ }^{3}$ • Hasan Yurdusev ${ }^{1}$ \\ ${ }^{1}$ Ministry of Food, Agriculture and Livestock, Çanakkale Provincial Directorate, 17100, Çanakkale, Turkey \\ ${ }^{2}$ Ege University, Faculty of Fisheries, 35100, Bornova, Izmir, Turkey \\ ${ }^{3}$ Çanakkale Onsekiz Mart University, Marine Science and Technology Faculty, 17100, Çanakkale, Turkey \\ *Corresponding Author: serhat_colakoglu@yahoo.com
}

\section{How to cite this paper:}

Çolakoğlu, S., Tokaç, A., Işmen,A.,Yurdusev, H., 2015. Catch composition of set net (fixed stake trap) fisheries in the coastal waters of Saros Bay, North Aegean Sea. Ege J Fish Aqua Sci 32(2): 53-58. doi: 10.12714/egejfas.2015.32.2.01

Özet: Ağ dalyan balıkçılı̆ı (sabit tuzak), Kuzey Ege Denizi’nde (Türkiye) Saros Körfezi'nin kıyı sularında geleneksel olarak yapılmaktadır. Bu balıkçוlık sistemleri kumlu çamurlu zeminler ile sığ deniz alanlarında balık yakalamak için kurulan pasif av araçlarıdır. 2010-2012 yılları arasında ağ dalyanları için balıkçıık sezonu olan Nisan-Ağustos dönemlerinde dört farklı ağ dalyanından avlanan balık türleri üzerinde çalışıııı̧̧ı. Araştırma bölgelerinden toplam 22 familyaya ait 37 balık türü yakalanmıştır. Baskın olan familyalar Clupeidae $(\% 45,65)$, Carangidae $(\% 16,51)$ ve Sparidae $(\% 13,24)$ olup, Sardina pilchardus $(\% 27,18)$, Sardinella aurita $(\% 18,47)$ ve Trachurus mediterraneus $(\% 16,42)$ adlı türlerin toplam av miktarı yakalanan tüm bireylerin \%62,07 sini oluşturmaktadır. Tüm dalyanlarda, tür çeşitliliği ( $H^{\prime \prime}$ log2) ve eşitlik indeksi $\left(\mathrm{J}^{\prime}\right)$ indeks değerleri sırasıyla 0 - 1,566 ve 0 - 0,999 arasında değişmektedir. Bu çalışma ile; ağ dalyan balıkçılı̆ının genel durumu irdelenmiş ve bu dalyanlarda avlanan balıkların bolluğu ve çeşitliliği hakkında bilgiler elde edilmiştir.

Anahtar kelimeler: Ağ dalyan balıkçılı̆ı, Av kompozisyonu, Tür çeşitliliği, Saros Körfezi, Kuzey Ege Denizi

\begin{abstract}
Set net (fixed stake trap) fisheries are performed according to traditional methods in the coastal waters of Saros Bay, North Aegean Sea (Turkey). These fisheries systems are the gear which is passively constructed for catching fish in shallow waters with sandy-muddy substrates. We studied the fish species caught by four set nets between April and August (set net fishing season) in 2010 - 2012. In total, 37 fish species belonging to 22 families were captured from the study areas. Clupeidae $(45.65 \%)$, Carangidae $(16.51 \%)$ and Sparidae (13.24\%) were determined as dominant families, and the total catch amount of dominant species, Sardina pilchardus (27.18\%), Sardinella aurita (18.47\%) and Trachurus mediterraneus $(16.42 \%)$, comprised $62.07 \%$ of the total catch. Species diversity (H'log2) and evenness $(\mathrm{J})$ index values calculated for all set nets were $0-1.566$ and $0-0.999$, respectively. This study provides some general information about the status of set net fisheries as well as the diversity and abundance of the species caught from the set nets.
\end{abstract}

Keywords: Set net fisheries, catch composition, diversity, Saros Bay, North Aegean Sea

\section{INTRODUCTION}

The set net (fixed stake trap) fishery is well known to be one of the oldest fishing methods in the world. Today, the set nets are used all over the word, particularly in the Far East (Japan, Taiwan etc.) (FAO, 2015). These fisheries systems are established with different sizes and types at certain times of the year (Deveciyan, 2011). In general, they consist of gear that is passively constructed for catching fish in shallow waters with sandy-muddy substrates. Setting up set nets in appropriate locations is also important in catching the fish that shoal in these set nets (Bök, 1991).

In different regions of the world, particularly in the Far
East, there have been several studies about diversity, catch composition and abundance so as to determine the potential catch of fixed stake trap fishing (Robertson and Duke, 1990; Liu et al., 1995; Chen et al., 1997; Jenq, 2004; 2010). However, relatively little is known regarding the status of set net fishing. Set net fisheries are used in the coastal areas of the Mediterranean Sea, Aegean Sea and Marmara Sea in Turkey. Along the coast of Saros Bay, these systems have been traditionally practised since the late 1970s. Set nets are constructed where the laws permit only these fishing operations in the region during the general fishing bans. Due to the high commercial value of the fish species, the set net fishery is one 
of the most important coastal fisheries methods along the coast of Saros Bay. In this region, there are a total of 15 trap systems, and these have caught more than 100 tonnes of fish as the annual average (Anonyms, 2013). In the Çanakkale region (part of the Sea of Marmara and North Aegean Sea), the annual catch production was approximately 10.700 tonnes in 2011 (Anonyms, 2012). This comprises approximately $1 \%$ of the total caught fish.

Relatively little is known about set net fisheries in Saros Bay or in Turkey. This study aimed to determine the species diversity and the potential of set net fisheries in Saros Bay. Furthermore, the results will provide some information about sustainable coastal fisheries management, species diversity, catch composition, and the status of set net fishing in these regions.

\section{MATERIAL AND METHOD}

\section{Set Net Catch Sampling and Collection of Data}

Each set net was regularly visited between April and August (the set net fishing season) in the years 2010-2012 in four locations along the coastal waters of Saros Bay in the North Aegean Sea (Turkey) (Figure 1).

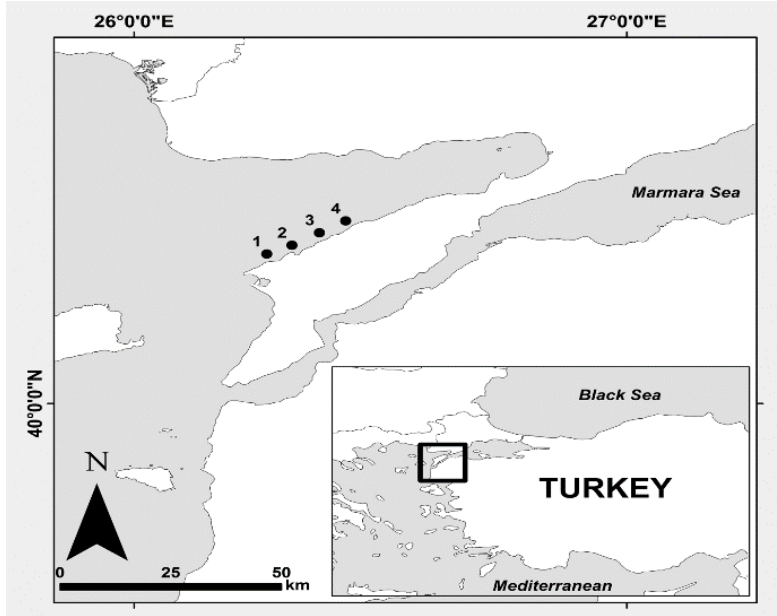

Figure 1. Sampling locations (1: M, 2: EL, 3: KL, 4: ML)

In general, fishing activity occurs from April to August (out of the normal fishing season) in Saros Bay. The mesh size and location of the set nets are listed in Table 1. We recorded the fish caught in one day, twice a week for each set net in the years $2010-2012$. In addition, the set net catches were collected from fishermen's logbooks of catch data obtained by weight.

Table 1. Set net location, depth and mesh size used in the study

\begin{tabular}{|c|c|c|c|c|}
\hline Location & Area & Coordinates & Depth (m) & Mesh size $(\mathrm{mm})$ \\
\hline \multirow[t]{4}{*}{ Saros Bay } & Mersinlik (M) & $40^{\circ} 21^{\prime} 09^{\prime \prime} \mathrm{N}-26^{\circ} 17^{\prime} 36^{\prime \prime} \mathrm{E}$ & $10-30$ & 10.5 \\
\hline & & $40 \circ 21^{\prime} 11^{\prime \prime} \mathrm{N}-26 \circ 17^{\prime} 40^{\prime \prime} \mathrm{E}$ & & \\
\hline & & $40^{\circ} 21^{\prime} 11^{\prime \prime} \mathrm{N}-26 \circ 17^{\prime} 39^{\prime \prime} \mathrm{E}$ & & \\
\hline & & $40^{\circ} 21^{\prime} 10^{\prime \prime} \mathrm{N}-26^{\circ} 17^{\prime} 36^{\prime \prime} \mathrm{E}$ & & \\
\hline \multirow[t]{4}{*}{ Saros Bay } & Ece Limanı $(E L)$ & $40^{\circ} 22^{\prime} 04^{\prime \prime} \mathrm{N}-26^{\circ} 19^{\prime} 27^{\prime \prime} \mathrm{E}$ & $15-30$ & 10.5 \\
\hline & & $40^{\circ} 22^{\prime} 07^{\prime \prime} \mathrm{N}-26 \circ 19^{\prime} 27^{\prime \prime} \mathrm{E}$ & & \\
\hline & & 40 ○ $22^{\prime} 04^{\prime \prime} \mathrm{N}-26 \circ 19^{\prime} 26^{\prime \prime} \mathrm{E}$ & & \\
\hline & & $40^{\circ} 22^{\prime} 07^{\prime \prime} \mathrm{N}-26^{\circ} 19^{\prime} 26^{\prime \prime} \mathrm{E}$ & & \\
\hline \multirow[t]{4}{*}{ Saros Bay } & Koyun Limanı $(K L)$ & $40^{\circ} 23^{\prime} 11^{\prime \prime} \mathrm{N}-26^{\circ} 21^{\prime} 43^{\prime \prime} \mathrm{E}$ & $10-25$ & 10.5 \\
\hline & & $40^{\circ} 23^{\prime} 13^{\prime \prime} \mathrm{N}-26^{\circ} 21^{\prime} 46^{\prime \prime} \mathrm{E}$ & & \\
\hline & & $40^{\circ} 23^{\prime} 13^{\prime \prime} \mathrm{N}-26^{\circ} 21^{\prime} 46^{\prime \prime} \mathrm{E}$ & & \\
\hline & & $40 \circ 23^{\prime} 10^{\prime \prime} \mathrm{N}-26 \circ 21^{\prime} 44^{\prime \prime} \mathrm{E}$ & & \\
\hline \multirow[t]{4}{*}{ Saros Bay } & Manda Limanı (ML) & $40^{\circ} 24^{\prime} 00^{\prime \prime} \mathrm{N}-26^{\circ} 23^{\prime} 09^{\prime \prime} \mathrm{E}$ & $10-30$ & 10.5 \\
\hline & & $40^{\circ} 24^{\prime} 01^{\prime \prime} \mathrm{N}-26^{\circ} 23^{\prime} 12^{\prime \prime} \mathrm{E}$ & & \\
\hline & & $40^{\circ} 24^{\prime} 01^{\prime \prime} \mathrm{N}-26^{\circ} 23^{\prime} 13^{\prime \prime} \mathrm{E}$ & & \\
\hline & & 40 ○ $23^{\prime} 59^{\prime \prime} \mathrm{N}-26 \circ 23^{\prime} 09^{\prime \prime} \mathrm{E}$ & & \\
\hline
\end{tabular}

\section{Gear Description}

Each fisheries system was constructed over a surface area of approximately 0.5 hectares ( $70 \mathrm{~m}$ width and $70-80 \mathrm{~m}$ length) at depths of up to 20-30 m, perpendicular to the shore in Saros Bay (North Aegean Sea). The set net was located just above the average low tide line and consisted of a leader net, an entrance, a slope, a bag net and a final trap and all of them supported by galvanised pipe poles (Figure 2). At each location, the mesh size of all parts of the set nets was usually 
constructed of $10.5 \mathrm{~mm}$ mesh. Four fishermen recovered the fish caught in the set net by removing the net in both final traps
(168 m2). Set nets were checked twice daily (at sunrise and sunset) and usually cleared only during low tide.

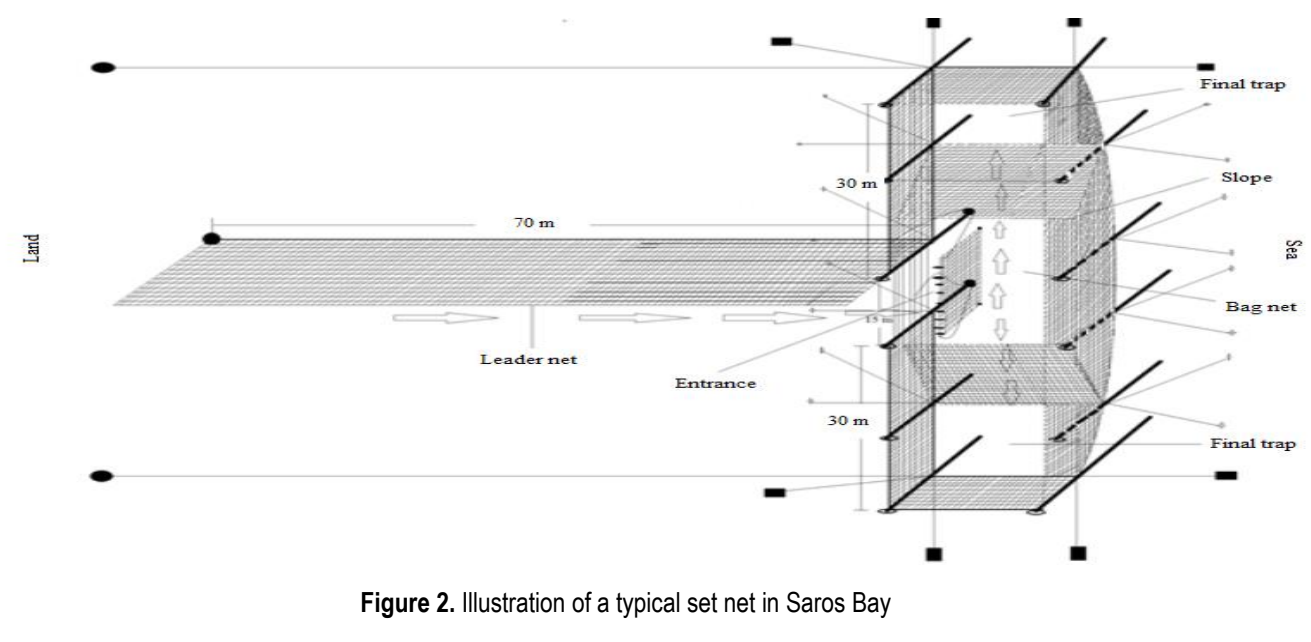

\section{Catch Composition and Diversity}

To evaluate spatial variation in the productivity of the set net fishery, CPUE of monthly dominant species was used in the study. The CPUE of a set net was calculated by dividing the total catch by the number of fishing days within the set net. CPUE values are given with standard error values.

$$
\text { CPUE }_{i}=\frac{\text { Catch }_{i}}{\text { Fishing days }}
$$

where Catchi is the sum of the catch within a set net and Fishing days is the sum of the fishing days in the set net. The differences between the total catch composition and CPUE were identified using Student $t$ tests (Zar, 1984). Significant differences were considered for $P<0.05$.

The Bray-Curtis similarity index was used to evaluate the similarities in the relationships between set nets. In this study, for each set net and month resulting from clustering, species diversity was estimated using the Shannon-Weaver diversity index $\left(\mathrm{H}^{\prime} \log 2\right)$ and Pielou's evenness index $\left(\mathrm{J}^{\prime}\right)$ from the mean biomass. Multivariate analyses were conducted using PRIMER v6.0 (Clarke and Warwick, 2001). Differences between months in species richness according to years were tested with a oneway ANOVA.

\section{RESULTS}

\section{Catch Composition}

Total variation among the fish caught from four locations during the set net fishing season (April - August) from 2010 to 2012 is shown in Table 2. The highest value was 30,258 $\mathrm{kg} / \mathrm{year}$ in 2012 and the lowest was 4,558 kg/year in 2010, with an average of approximately 19,840 kg/year. The captures for each set net show variation. The highest amount was caught in 2010 at ML (3,070 kg/year), in 2011 at M (12,843 kg/year) and in 2012 at $\mathrm{EL}(14,453 \mathrm{~kg} / \mathrm{year})$. The most fish were captured from the set net in EL (average 7,246 kg/year).

Table 3 lists the total abundance of five fish species most caught as mean CPUE in kilograms per day, for four locations between April and August. We determined the highest CPUE value in 2010 at ML (Sardina pilchardus; average 6.47 \pm 0.16 $\mathrm{kg} /$ day), in 2011 at M (Sardinella aurita; average 12.47 \pm 1.19 $\mathrm{kg} /$ day) and in 2012 at EL (Trachurus mediterraneus; average $10.75 \pm 0.48 \mathrm{~kg} / \mathrm{day}$ ). The species bogue (Boops boops) was captured from all set nets in every year. In addition, the t-test results revealed no significant differences in the mean biomass between the total catch composition and CPUE for five fish species in all set nets $(P<0.05)$.

\section{Diversity}

A total of 39 fish species, representing 23 families, were captured from four set nets (Table 2). The maximum average number of fish species captured was 22 in 2012 and the minimum average number was 14 in 2010. Of the fishes caught from the four set nets, approximately $89 \%$ comprise six fish species, including sardine (S. pilchardus, $27.18 \%$ ); round sardinella (S. aurita, 18.47\%); mackerel (T. mediterraneus, $16.42 \%$ ); bogue (B. boops, $12.30 \%$ ); picarel (Spicara smaris, $10.21 \%$ ) and yellowstripe barracuda (Sphyraena chrysotaenia, $4.37 \%$ ) (Table 2). The total annual catch of these six most prevalent species was determined as stable every year. However, in 2010, sardine (S. pilchardus) was observed as unstable with catches from only the set net in $\mathrm{ML}$. Approximately $99 \%$ of fishes caught in the study were pelagic species. The same captured species (S. pilchardus, S. aurita and $T$. mediterraneus) dominated in four different set nets. The highest average species diversity was obtained from set nets at ML (16) in 2010, M (24) in 2011 and EL (24) in 2012 (Table 2). 
Table 2. The distribution of total weight $(\mathrm{kg})$ of fish species caught from four set nets by year $(2010-2012)$.

\begin{tabular}{|c|c|c|c|c|c|c|c|c|c|c|c|c|c|c|}
\hline \multirow[b]{2}{*}{ Family } & \multirow[b]{2}{*}{ Species } & \multicolumn{4}{|c|}{2010} & \multicolumn{4}{|c|}{2011} & \multicolumn{4}{|c|}{2012} & \multirow[b]{2}{*}{$\%$} \\
\hline & & $E L$ & $K L$ & $M L$ & $M$ & $E L$ & $K L$ & $M L$ & $M$ & $E L$ & $\overline{K L}$ & $M L$ & $M$ & \\
\hline \multirow[t]{2}{*}{ Clupeidae } & Sardina pilchardus & - & - & 1,980 & - & - & 12 & 3,108 & 3,132 & 3,120 & 684 & 3,012 & 1,128 & 27,18 \\
\hline & Sardinella aurita & 180 & 84 & 276 & 216 & 936 & 110 & 12 & 3,816 & 3,216 & 638 & - & 1,512 & 18,47 \\
\hline \multirow[t]{2}{*}{ Carangidae } & Trachurus mediterraneus & - & 44 & 84 & 108 & 1,152 & 12 & 84 & 708 & 3,288 & 1,332 & - & 2,964 & 16,42 \\
\hline & Licia amia & - & - & 14 & - & 2 & - & - & 40 & - & - & - & - & 0,09 \\
\hline Belonidae & Belone belone & 12 & 12 & 72 & 48 & 72 & - & 228 & 204 & 876 & 72 & 516 & 228 & 3,93 \\
\hline Sphyraenidae & Sphyraena chrysotaenia & 84 & 24 & 324 & 96 & 264 & - & 72 & 573 & 348 & 72 & 60 & 684 & 4,37 \\
\hline \multirow[t]{2}{*}{ Centracanthidae } & Spicara smaris & 27 & 120 & 60 & 60 & 2,340 & 48 & 432 & 1,716 & 696 & 228 & - & 348 & 10,21 \\
\hline & Spicara maena & - & - & - & - & - & - & - & - & - & 4 & 1 & - & 0,01 \\
\hline Mugilidae & Mugil cephalus & 24 & 12 & - & - & 168 & - & 360 & 768 & 228 & - & - & 168 & 2,90 \\
\hline Atherinidae & Atherina boyeri & - & - & - & - & - & - & - & - & 14 & 1 & - & - & 0,03 \\
\hline Loliginidae & Loligo vulgaris & 1 & 1 & 20 & 2 & 24 & - & 7 & 54 & 38 & 21 & 24 & 17 & 0,35 \\
\hline \multirow[t]{3}{*}{ Scombridae } & Scomber japonicus & - & - & 24 & - & 48 & 12 & 24 & 240 & 156 & 12 & 120 & 180 & 1,37 \\
\hline & Scomber scombrus & - & - & - & - & - & - & - & - & 6 & 4 & - & 24 & 0,06 \\
\hline & Sarda sarda & 2 & 11 & 4 & - & 3 & - & 6 & 129 & 32 & - & - & 22 & 0,35 \\
\hline Pomatomidae & Pomatomus saltatrix & - & - & 15 & 17 & - & 16 & 25 & 51 & 31 & 10 & 16 & 29 & 0,35 \\
\hline \multirow[t]{7}{*}{ Sparidae } & Diplodus vulgaris & - & 4 & 12 & 9 & 9 & 1 & 12 & 33 & - & - & 2 & 3 & 0,14 \\
\hline & Diplodus annularis & 1 & - & - & 1 & 7 & - & - & 1 & 13 & 1 & 1 & - & 0,04 \\
\hline & Diplodus sargus sargus & - & - & - & - & - & - & - & - & 2 & - & - & - & 0,003 \\
\hline & Lithognathus mormyrus & - & - & - & - & - & - & - & 2 & 2 & - & - & - & 0,007 \\
\hline & Oblada melanura & 2 & 1 & 2 & 7 & 1 & - & - & 25 & 90 & 7 & 11 & 27 & 0,29 \\
\hline & Pagellus bogaraveo & - & - & - & - & - & - & - & 10 & 82 & 30 & 1 & 1 & 0,21 \\
\hline & Pagellus acerna & - & - & - & - & - & - & - & - & - & 2 & - & - & 0,003 \\
\hline \multirow[t]{5}{*}{ Sparidae } & Sarpa salpa & 12 & - & - & - & - & - & - & 48 & 48 & 12 & - & 2 & 0,20 \\
\hline & Boops boops & 84 & 48 & 180 & 120 & 1,812 & 35 & 96 & 1,272 & 2,160 & 612 & 432 & 468 & 12,30 \\
\hline & Spondyliosoma cantharus & 1 & - & - & - & 1 & - & 3 & - & 4 & 1 & 3 & 6 & 0,03 \\
\hline & Sparus auratus & - & - & - & - & 1 & - & - & 2 & 1 & - & 1 & - & 0,008 \\
\hline & Dentex dentex & - & - & - & - & - & 2 & - & - & 1 & - & - & - & 0,005 \\
\hline Merlucciidae & Merluccius merluccius & - & - & - & - & - & - & - & - & 1 & - & 1 & - & 0,003 \\
\hline Octopodidae & Octopus vulgaris & 1 & - & 2 & 1 & 2 & - & - & 2 & - & - & - & 2 & 0,017 \\
\hline Engraulidae & Engraulis encrasicolus & - & - & - & - & - & - & 288 & - & - & - & 36 & 1 & 0,55 \\
\hline Scorpaenidae & Scorpaena scrofa & - & - & - & - & - & - & - & - & - & 2 & 1 & 2 & 0,008 \\
\hline Sepiidae & Sepia officinalis & - & - & - & - & - & - & - & - & - & 2 & - & - & 0,003 \\
\hline Ommastrephidae & Todarodes sagittatus & - & - & - & - & - & - & - & - & - & 1 & 1 & - & 0,003 \\
\hline \multirow[t]{2}{*}{ Mullidae } & Mullus surmelatus & - & - & - & - & - & - & - & - & - & 1 & - & 1 & 0,003 \\
\hline & Mullus barbatus & - & 1 & 1 & 1 & 2 & - & 2 & 5 & - & - & - & - & 0,02 \\
\hline Holocentridae & Sargocentrum rubrum & - & - & - & - & - & 0,008 & - & - & - & - & - & - & - \\
\hline Moronidae & Dicentrarchus labrax & 1 & - & - & 7 & 3 & - & 1 & 1 & - & - & - & - & 0,02 \\
\hline Sciaenidae & Corvina umbra & - & - & - & - & 6 & - & - & 11 & - & - & - & - & 0,029 \\
\hline \multirow[t]{2}{*}{ Pleuronectidae } & Platichthys flesus & - & - & - & 1 & 1 & - & - & - & - & - & - & - & 0,003 \\
\hline & TOTAL & & & 3,07 & & 6,854 & 248 & 4,760 & 12,843 & 14,453 & 3,749 & 4,239 & 7,817 & 59,521 \\
\hline
\end{tabular}


Table 3. The distribution of CPUE values ( $\mathrm{kg} / \mathrm{day}$ ) of the five most frequently caught fish species from four set nets by year (2010 - 2012).

\begin{tabular}{|c|c|c|c|c|c|c|c|c|c|c|c|c|}
\hline \multirow[b]{2}{*}{ Species } & \multicolumn{4}{|c|}{2010} & \multicolumn{4}{|c|}{2011} & \multicolumn{4}{|c|}{2012} \\
\hline & $E L$ & $K L$ & $M L$ & $M$ & $E L$ & $K L$ & $M L$ & $M$ & $E L$ & $K L$ & $M L$ & $M$ \\
\hline S. pilchardus & - & - & 6,47 & - & - & 0,04 & 10,16 & 10,24 & 10,20 & 2,24 & 9,84 & 3,69 \\
\hline S. aurita & 0,59 & 0,27 & 0,90 & 0,71 & 3,06 & 0,36 & 0,04 & 12,47 & 10,51 & 2,08 & - & 4,94 \\
\hline T. mediterraneus & - & 0,14 & 0,27 & 0,35 & 3,76 & 0,04 & 0,27 & 2,31 & 10,75 & 4,35 & - & 9,69 \\
\hline S. smaris & 0,09 & 0,39 & 0,20 & 0,20 & 7,65 & 0,16 & 1,41 & 5,61 & 2,27 & 0,75 & - & 1,14 \\
\hline B. boops & 0,27 & 0,16 & 0,59 & 0,39 & 5,92 & 0,11 & 0,31 & 4,16 & 7,39 & 2,0 & 1,41 & 1,53 \\
\hline
\end{tabular}

In this study, we observed an increase in species diversity from 2010 to 2012. Species diversity was found to be high in May every year. In April of 2010 the average minimum diversity caught was 9 . The maximum diversity (28) was observed in May of 2012 and an average of 20 species were caught and in all locations. There were no significant differences $(P<0.05)$ between monthly species richness according to years $[F$ test $(4,10)=2.227, P=0.139]$.

The Bray-Curtis similarity index was used to allow better visualisation of month-to-month similarity in set nets in the fishing season (April-August) (Figure 3). The dendrogram clusters the most similar samples and separates the most dissimilar samples. Those set nets that are clustered lower on

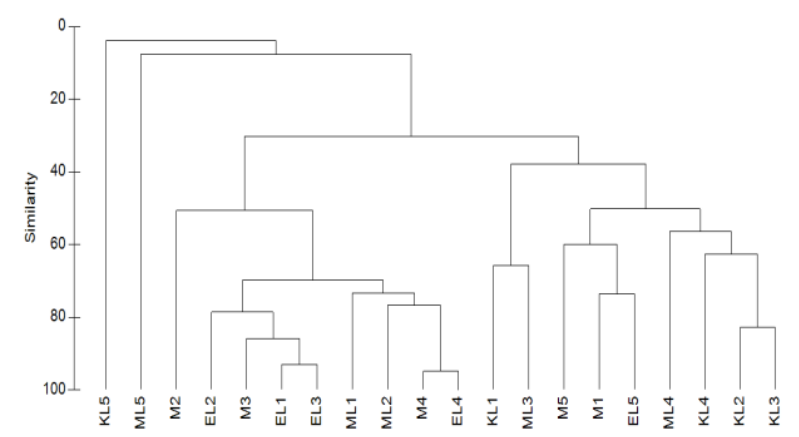

Figure 3. Bray-Curtis similarity dendrogram of fish species caught the set nets

\section{DISCUSSION}

The set net trap is one of the most important fishing methods used in coastal fisheries of Saros Bay. Species migrating along the coastal areas of Saros Bay and utilising them for feeding, nursing and spawning grounds are caught by the set nets. In this study, 39 species, representing 23 families, were captured by the set nets at four locations. There is an abundance of commercial pelagic species such as the dendrogram are most similar (i.e. EL1, EL3, M4, EL4). Fishes caught in August from the KL and ML set nets appeared as different groups in the analysis. These results indicate an overall similarity of approximately $37 \%$, apart from the KL5 and ML5 set nets (Figure 3). The highest species diversity $\left(\mathrm{H}^{\prime}\right)$ and evenness index (J') values were observed in May $(1.566, \mathrm{ML})$ and July $(0.999, M)$, respectively. The lowest species diversity $\left(\mathrm{H}^{\prime}\right)$ and evenness index $\left(\mathrm{J}^{\prime}\right)$ values were observed as zero in April, July and August (KL) and August (ML). The species diversity ( $\left.\mathrm{H}^{\prime}\right)$ and evenness index (J') values of group 1 (KL5) and group 2 (ML5) significantly differed from those of group 3 (M2, EL2, M3, EL1, EL3, ML1, ML2, M4, EL4) and group 4 (KL1, ML3, M5, M1, EL5, ML4, KL4, KL2, KL3) $(P<0.01)$ (Figure 4).

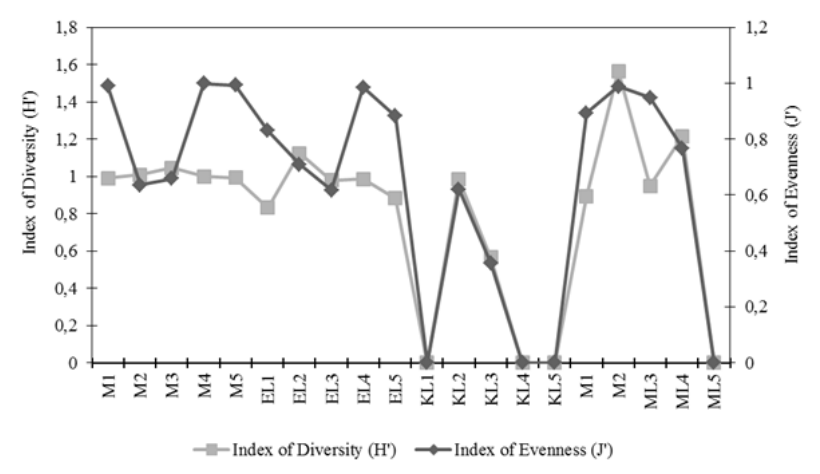

Figure 4. Variations in $\mathrm{H}^{\prime} \log 2$ and $\mathrm{J}$ ' of the catch in the set nets

Scombridae, Carangidae, Istiophoridae, Belonidae, Coryphaenidae, Clupeidae and Molidae in the coastal waters of Saros Bay (İşmen et al., 2007). In China, 126 species were identified in the samples, including 102 fish species, 17 crustaceans, five Cephalopoda and two Medusa species, caught from set nets in the Yellow and Bohai Seas (Chen et al. 1997). Abou-Seedo (1992) reported the capture of a total of 76 species, representing 36 families, using a hadrah (fixed stake trap) in Kuwait Bay. Twenty-six dominant catch species, 
including nine Scombridae, four Carangidae and 13 other families, have been determined from set nets along the eastern coast of Taiwan (Jenq, 2010).

In this study, species diversity $\left(\mathrm{H}^{\prime} \log 2\right)$ and evenness index $(\mathrm{J} ')$ values calculated for all set nets were $0-1.566$ and $0-$ 0.999 , respectively. A study conducted using a set net along the eastern coast of Taiwan determined species diversity and evenness indices of $1.16-1.63\left(\mathrm{H}^{\prime}\right)$ and $1.20-1.63\left(\mathrm{~J}^{\prime}\right)$ respectively (Jenq, 2010). According to our species diversity $\left(\mathrm{H}^{\prime} \log 2\right)$ analysis, the average value at $\mathrm{M}$ was higher than that of the other set nets (April-August, the set net fishing season) and the value at ML was highest in May (1.566). The annual capture and abundance of species with set nets are almost affected by year. In Saros Bay, catches were at their lowest in 2010, whereas the record annual catches at the set nets fishing ground were at their highest in 2012. Although the set nets on the fishing grounds ( $\mathrm{M}, \mathrm{EL}, \mathrm{KL}$ and $\mathrm{ML}$ ) were identical along the coast of Saros Bay, the abundant fishing periods differed owing to the different locations of fishing sites. In addition, further studies on the differences in marine environmental factors or marine conditions affecting variances in fishing conditions among these set net fishing sites are required. In particular, in 2010, we observed mucilage resulting from a pollution source in the Sea of Marmara, along with the North Aegean Sea and

\section{REFERENCES}

Anonyms, 2012. Ministry of Food, Agriculture and Livestock, Çanakkale Provincial Directorate Statistics, Çanakkale, Turkey.

Anonyms, 2013. Ministry of Food, Agriculture and Livestock, Çanakkale Provincial Directorate Statistics, Çanakkale, Turkey.

Abou-Seedo, F.S., 1992. The abundance of fish caught by stake-traps (hadrah) in the intertidal zone in Doha, Kuwait Bay. J. Univ. Kuwait-Sci. 19(1), 91 99.

Bök, T., 1991. Beykoz Dalyanı'nın işleyişi ve avcılığı üzerine araştırmalar. İstanbul Üniversitesi. Yüksek Lisans Tezi. (3), 61.

Chen, D., Liu, Q., Zeng, X., Su, Z., 1997. Catch composition and seasonal variation of set-net fisheries in the Yellow and Bohai Sea. Fisheries Research, 32, 61-68. doi: 10.1016/S0165-7836(97)00043-X

Clarke, K.R., Warwick, R.M., 2001. Change in marine communities: an approach to statistical analysis and interpretation, second ed., PRIMER E: Plymouth.

Deveciyan, K., 2011. Türkiye'de Balık ve Balıkçılık. Aras Yayıncılık, İstanbul, 2011.

FAO, 2015. http://www.fao.org/fishery/geartype/219/en

İşmen, A., Özen, O., Altınağaç, U., Özekinci, U., Ayaz, A., 2007. Weight-length relationships of 63 fish species in Saros Bay, Turkey. J. Appl. Ichthyol. 23 707-708. doi: 10.1111/j.1439-0426.2007.00872.x
Saros Bay. The gelatinous algae secretions (mucilage) entered the nutrition competition and excessively increased phytoplankton composition in the sea (Tüfekçi et al., 2010). It is believed that this was the main cause of the decrease in species diversity and productivity of set nets in 2010. Tokaç et al., 1991 studied on the using of modern set net (Japanese type) in Turkish Seas and reported that demersal, semi-pelagic and pelagic species are caught together by this type of the set nets. It has also been reported that the important part of the catch is composed of red mullet, horse mackerel, boce, sole and especially shrimp.

The present study aims to determine the general status of set net fishing carried out in the coastal line of Saros Bay in the North Aegean Sea. To achieve this goal, catch composition, species diversity and abundance were investigated for the set net fishing method. In addition, the findings obtained from this research will aid in facilitating the development of conservation and sustainable fishing policies for set net fishing in Saros Bay.

\section{ACKNOWLEDGEMENTS}

The authors thank to Ali Yıldırım, A. Kadri Varlık and Necmi Pamukçu for their kindly help in the field work.

Jenq, H.Y., 2004. Bycatch and discard of set-net fisheries in Taiwan. FRI Special Publication, 5, 139-146.

Jenq, H.Y., 2010. Studies on the variation of fishing condition at Chiafong setnet fishing company. Bulletin of National Kaohsiung Marine University, 24, 43-66.

Liu, C.C., Jiang, J.J., Jenq, H.Y., Ou, H.C., 1995. Studies of species composition and secular fluctuations of catch by set-net on the Shih-YuShan fishing ground. China fisheries (monthly), 514, 17-37.

Robertson, A.L., Duke, N.C., 1990. Mangrove fish communities in tropical Queensland, Australia: spatial and temporal. Marine Biology, 104:369379.doi: 10.1007/BF01314339

Tokaç, A., Gurbet, R., Alpbaz, A. 1991. Modern ağ dalyanların Türkiye'de uygulanabilirliği üzerine bir ön çalışma. Ege J. Fish Aqua Sci. Cilt:8 Sayı:29-30, Bornova İzmir.

Tüfekçi, V., Balkıs, N., Beken, P.C.., Ediger, D., Mantıkçı, M., 2010. Phytoplankton composition and environmental conditions of a mucilage event in the Sea of Marmara. Turkish Journal of Zoology, 34, 199-210. doi: 10.3906/biy-0812-1

Zar, J.H., 1984. Biostatistical Analysis. 2nd ed. Prentice Hall, Englewood Cliffs, NJ 